\title{
Potential role of blood dendritic cells in elicitation phase of contact hypersensitivity response - preliminary study
}

\author{
Potencjalna rola komórek dendrytycznych krwi w fazie efektorowej nadwrażliwości \\ kontaktowej - badanie wstępne
}

Aleksandra Lesiak', Igor A. Bednarski², Anna Woźniacka', Joanna Narbutt'

'Department of Dermatology and Venereology, Medical University of Lodz

2Student Research Group at Department of Dermatology, Medical University of Lodz

Przegl Dermatol 2016, 103, 197-201

DOI: 10.5 | |4/dr.2016.60629

\section{KEY WORDS:}

dendritic cells, contact hypersensitivity response, elicitation phase.

SŁOWA KLUCZOWE:

komórki dendrytyczne, nadwrażliwość kontaktowa, faza efektorowa.
ADDRESS FOR CORRESPONDENCE:

Aleksandra Lesiak MD, PhD

Department of Dermatology and Venereology

Medical University of Lodz

5 Krzemieniecka St

94-017 Lodz, Poland

phone: +48426867981

e-mail: lesiak_ola@interia.pl

\begin{abstract}
Introduction. In contrast to our broad knowledge about the role of dendritic cells in the sensitization phase of the contact hypersensitivity response (CHS), very little is known about their function in the effector phase. The pathophysiological mechanism of blood dendritic cells' participation in the inflammatory response in CHS is an emerging subject of study and needs to be scrutinized.

Objective. To assess the presence and type of human blood dendritic cells (BDC) - plasmacytoid DC (pDC) and myeloid DC (mDC) - at the elicitation site of CHS.

Material and methods. The study group consisted of 25 healthy volunteers with a mean age of $22.3 \pm 6.1$. Each patient before the trial was sensitized with DPCP, and after 3 weeks skin biopsies were taken from the elicitation site and were immunohistochemically stained with monoclonal mouse IgG1 antibodies against blood dendritic cell antigens (BDCA).

Results. Skin biopsies were divided into two groups: group 1 where the CHS score was assessed as 0 (no reaction; $n=7$ ) and group 2 where the CHS score was assessed as 1 (any response noted; $n=18$ ). Compared to group 1, group 2 had a significantly lower percentage of pDC (60\% vs. $15 \%$ respectively) in the inflammatory infiltrate site. We also observed that the percentage of $\mathrm{mDC}$ was higher in group 2 compared to group 1 , although this result was not statistically significant.

Conclusions. Our findings provide some data on composition of inflammatory infiltrate in the elicitation phase of CHS. We suggest that the imbalance between $\mathrm{pDC}$ and $\mathrm{mDC}$ may be a key to understanding the effector phase of CHS.
\end{abstract}

\section{STRESZCZENIE}

Wprowadzenie. W przeciwieństwie do dobrze poznanej roli komórek dendrytycznych w fazie indukcji nadwrażliwości kontaktowej (ang. contact hypersensitivity response - CHS), niewiele wiadomo na temat ich roli w fazie efektorowej. Patofizjologiczny mechanizm udziału komórek dendrytycznych $\mathrm{w}$ procesie nadwrażliwości kontaktowej jest nowym kierunkiem badań, który powinien zostać szczegółowo przeanalizowany. 
Cel pracy. Określenie obecności i typu ludzkich komórek dendrytycznych krwi (ang. blood dendritic cells - BDC): plazmacytoidalnych (pDC) i mieloidalnych (mDC), w miejscu fazy efektorowej CHS.

Materiał i metodyka. Grupa badana składała się z 25 zdrowych ochotników (średnia wieku: 22,3 $\pm 6,1 \mathrm{roku}$ ). Wszyscy uczestnicy przed rozpoczęciem badania zostali uczuleni DPCP. Po 3 tygodniach z miejsc fazy efektorowej CHS zostały od nich pobrane wycinki skóry, które następnie wybarwiono immunohistochemicznie za pomocą monoklonalnego mysiego przeciwciała w klasie IgG1 skierowanego przeciwko antygenom komórek dendrytycznych (ang. blood dendritic cells antigens - BDCA).

Wyniki. Wycinki skóry zostały podzielone na dwie grupy: grupa 1., gdzie reakcja CHS nie wystąpiła $(n=7)$, i grupa 2., gdzie CHS wystąpiło $(n=18)$. W porównaniu z grupą 1 . $\mathrm{w}$ grupie 2 . zaobserwowano niższy odsetek pDC (odpowiednio $60 \%$ vs $15 \%$ ) w miejscu nacieku zapalnego. Stwierdzono także odwrotną tendencję - liczba mDC była wyższa w grupie 2., jednak wynik nie był istotny statystycznie.

Wnioski. Na podstawie przeprowadzonego badania uzyskano dane na temat składu nacieku zapalnego w fazie efektorowej CHS. Wydaje się, że brak równowagi między pDC i mDC może się okazać kluczowy w rozwoju fazy efektorowej CHS.

\section{INTRODUCTION}

Described in 1973, dendritic cells (DC) along with macrophages and $\mathrm{B}$ lymphocytes are regarded as one of the main groups of antigen-presenting cells (APC), and they represent less than $1 \%$ of peripheral blood mononuclear cells (PBMC) [1]. The distinction from similar cells, such as monocytes and macrophages, was based on their unique morphology $[2,3]$. Dendritic cells' population heterogeneity, in terms of cluster of differentiation markers (CD), function, and anatomic location, is derived from separate bone marrow (CD34+ stem cells) hematopoietic lineages [4]. It has been proven that DC are efficient stimulators of both T-cell proliferation in mixed leukocyte reactions and the antigen-specific T-cell response [5, 6]. There are three main subpopulations of dendritic cells in human blood - two myeloid dendritic cell subsets (mDC1 and $\mathrm{mDC} 2$ ) and one plasmacytoid subset ( $\mathrm{pDC}$ ) - but this division only includes their presumed origin [7]. All of these blood dendritic cell
(BDC) subsets also vary in expression of Toll-like receptors, produced cytokines and response to pathogens (Table 1) [8]. Both subtypes of myeloid DC secrete IL-12; thus they are responsible for differentiation of Th1 cells from naïve T cells and production of interferon $\gamma(\mathrm{IFN}-\gamma)$ and tumor necrosis factor $\alpha$ (TNF- $\alpha$ ) from natural killer cells (NK) and T cells [9]. This suggests that $\mathrm{mDC}$ may also recognize several bacterial components. On the other hand, pDC play a pivotal role in anti-viral defense, by producing interferons (IFN- $\alpha$ and IFN- $\beta$ ), although in chronic viral infections (HIV, HCV) their amount in the circulation decreases [10-13].

The role of dendritic cells in the contact hypersensitivity response seems to be crucial, yet poorly understood. Although some data clearly underline the key role of dendritic cells in the sensitization phase of CHS, there are only scarce data regarding their role in the elicitation (effector) phase. Bangert et al. [14] found not only CD1c+ dendritic cells (Langerhans cells) in inflammatory infiltrate, but also BDCA-2+,

Table I. Immunophenotypic characteristics of peripheral blood dendritic cell (BDC) subpopulation

Tabela I. Charakterystyka immunofenotypowa subpopulacji komórek dendrytycznych knwi obwodowej

\begin{tabular}{|c|c|c|}
\hline BDC subset & $\begin{array}{l}\text { BDCA (peripheral blood } \\
\text { dendritic cell antigen) }\end{array}$ & Expression of other antigens \\
\hline Plasmacytoid (pDC) & BDCA-2, BDCA-4 & CDI23+, CDIIC-, CD4+, CD2-, CD45RO+ \\
\hline Myeloid I (mDCl) & BDCA-I (CDIC) & $\begin{array}{c}\text { Lin-, HLA-DR+, CD I I c cright, CD I 23 dim, CD2 +, CD4+, CD45RO+ } \\
\text { CDI3 +, CD33+ (myeloid lineage markers) } \\
\text { CD32+, CD64+, Fc RI+ (Fc receptors) }\end{array}$ \\
\hline Myeloid 2 (mDC2) & BDCA-3 & As mDCl, but: CDI I clow, CDI23dim, CD2- CD32-, CD64-, Fc Rl- \\
\hline
\end{tabular}




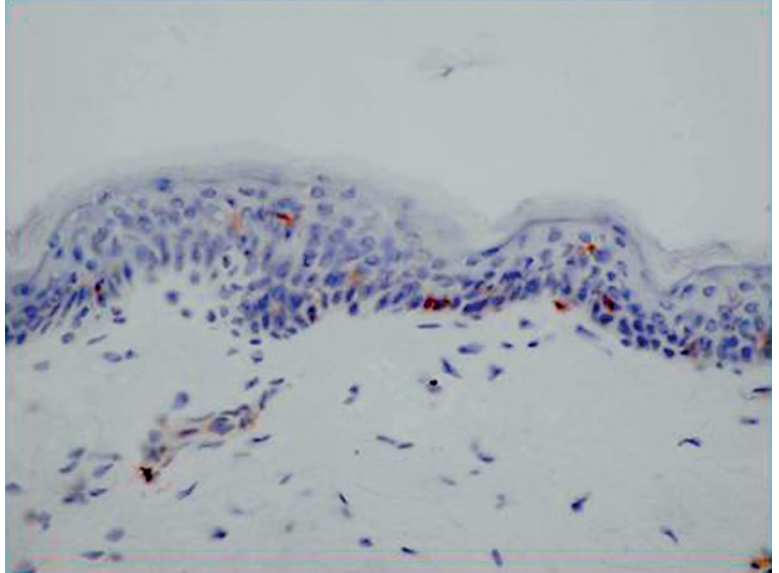

Figure I. Immunohistochemical staining for BDCA- I

Rycina I. Barwienie immunohistochemiczne na obecność BDCA-I

CD123+, CD45RA+, and CD62L+ plasmacytoid dendritic cells. Girard-Madoux et al. [15] revealed that deficiency in IL-10, which regulates maturation of DC and proinflammatory cytokine secretion, results in an excessive CHS response. The above facts suggest that BDC can be involved in contact dermatitis development and immune cutaneous surveillance.

\section{OBJECTIVE}

The aim of our study was to assess the role of human blood dendritic cells - plasmacytoid DC (BDCA-2, BDCA-4) and myeloid DC (BDCA1, BDCA3) - at the elicitation site of CHS.

\section{MATERIAL AND METHODS}

The study group consisted of 25 healthy volunteers with a mean age of $22.3 \pm 6.1$ (12 females, 13 males aged 18-36 years) with skin phototype II or III, as assessed by Fitzpatrick scoring system [16]. We selected these phototypes as they are found in the majority of the Central Europe population. They had no skin or other disease and were neither receiving nor taking any medication. Subjects exposed to the contact allergen diphenylcyclopropenone (DPCP) were excluded. Signed informed consent was taken from all participants before enrollment in the study. The study design was accepted by the local ethics committee of the Medical University of Lodz, no. RNN/48/2001/KE.

All the volunteers were sensitized with DPCP. Elicitation of CHS took place 3 weeks after exposure to DPCP. Responses were evaluated after $48 \mathrm{~h}$ by a subjective visual scoring system, and a $3 \mathrm{~mm}$-punch skin biopsy was taken from the $3.2 \mathrm{mg}$ DPCP elicitation site in each subject and was immunohistochemi-

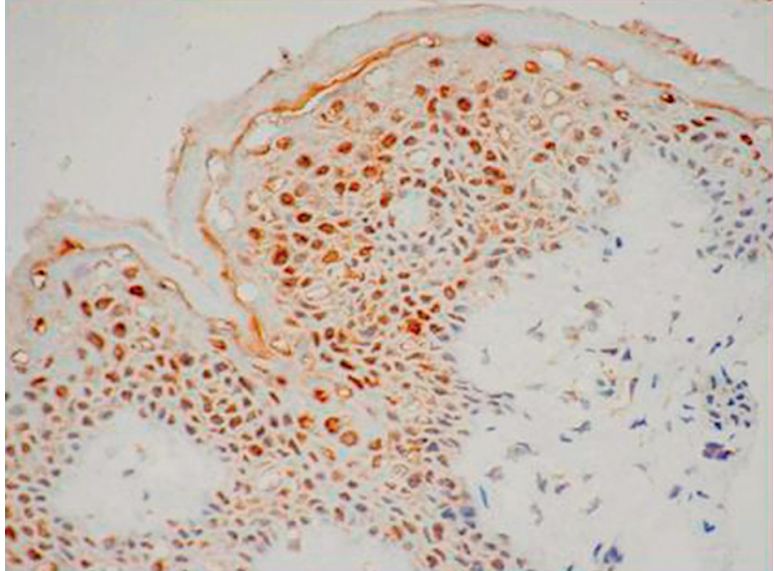

Figure 2. Immunohistochemical staining for BDCA-2

Rycina 2. Barwienie immunohistochemiczne na obecność BDCA-2

cally stained with monoclonal mouse IgG1 antibodies directed against BDCA-1, BDCA-2, BDCA-3, and BDCA-4 (Miltenyi Biotec, Bergish Gladback, Germany) [17] and presence of plasmacytoid (pDC) and myeloid (mDC) blood dendritic cells was analyzed (Figures 1 and 2). In each specimen, the staining intensity of BDCA-1, BDCA-2, BDCA-3, and BDCA-4 was recorded by two independent observers in 6-8 adjacent high-power fields and graded as 0 (lack of cells in epidermis and/or dermis) or 1 (presence of any cells in epidermis and/or dermis). In each group the number of plasmacytoid DC (BDCA-2, BDCA-4) and myeloid DC (BDCA1, BDCA3) was counted, and then the percentage of BDC was evaluated in groups 1 and 2 .

\section{Statistical analysis}

For statistical analysis the $\chi^{2}$ test and Fisher's exact test were applied. Values of $p<0.05$ were considered statistically significant.

\section{RESULTS}

Based on the visual score of CHS the volunteers were divided into two groups: group $1(0.00)$ where the CHS score was assessed as 0 (no reaction; $n=7$ ) and group 2 (1.00) where the CHS score was assessed as 1 (any response noted; $n=18$ ). The presence of $\mathrm{pDC}$ was observed in a significantly higher percentage of subjects from group $1(60 \%)$ compared to group $2(15 \%)(p=0.043)$. mDC cells were present in a higher percentage in subjects from group 2 than those from group 1. However, the difference was not statistically significant $(p>0.05)$. The statistical analysis also revealed that presence of BDCA-1 does not depend on study group $(p>0.05)$, while presence of BDCA-4 does $(p<0.05)$. These results are shown in Figure 3. 

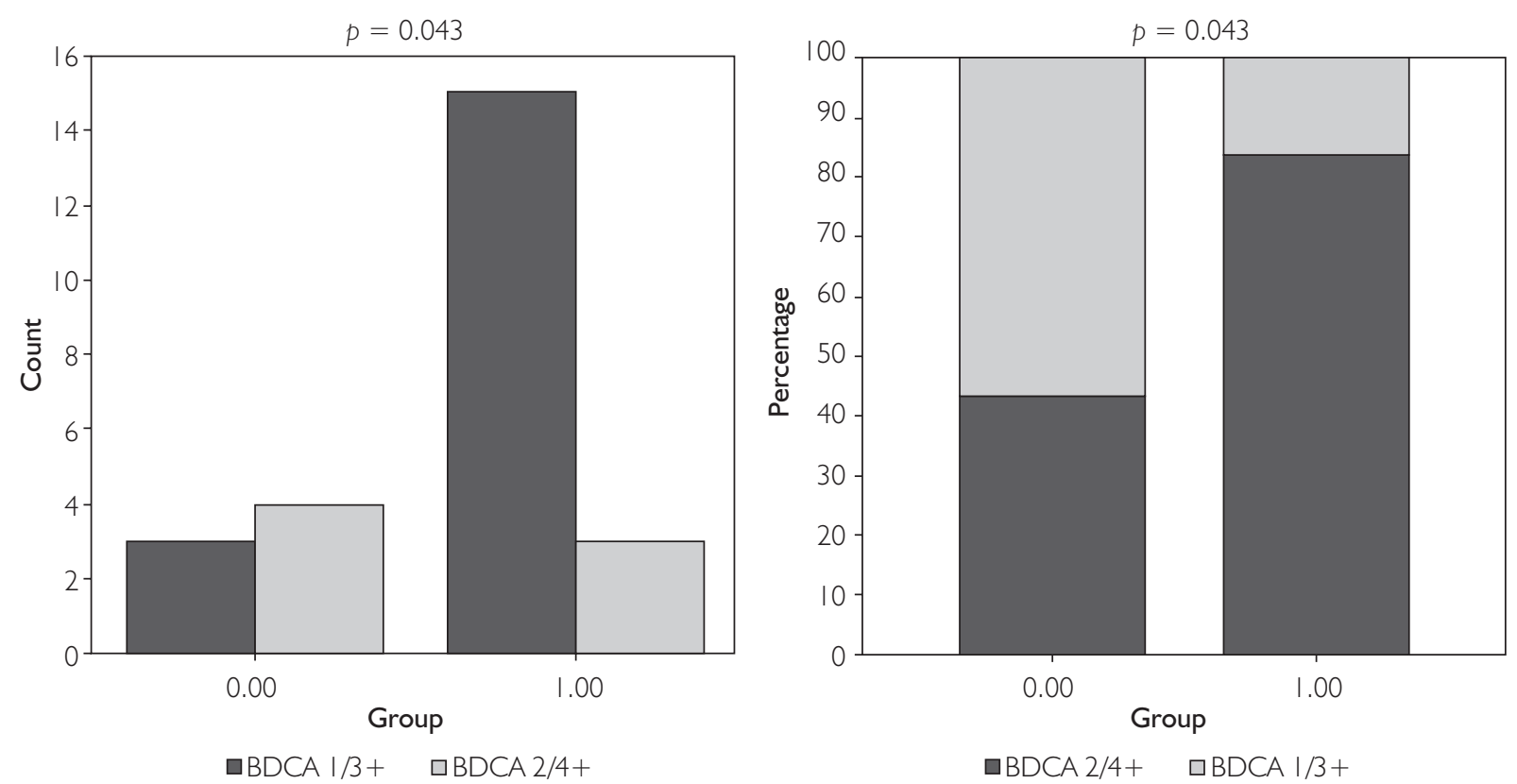

Figure 3. Number and percentage of $\mathrm{pDC}$ and $\mathrm{mDC}$ in analyzed groups

Rycina 3. Liczba i procent pDC i mDC w analizowanych grupach

\section{DISCUSSION}

Contact hypersensitivity is a T cell-mediated, delayed skin inflammatory process induced by skin exposure to low-weight haptens in sensitized individuals. For a long time it has been considered that antigen-specific CD4+ T cells are essential in development of CHS, although recent findings have shown that dendritic cells, both present in the skin (LC - interstitial cells) and migrating from the blood (pDC), orchestrate the immunological cutaneous response [18-20]. These potent leukocytes, normally absent in human skin, in response to various immunological stimuli, migrate into the epidermis and dermis, to regulate the response of $\mathrm{T}$ cells. Our previous study showed that UV radiation suppresses CHS and influences the Langerhans cell count [21]. Other factors affecting the DC count include microbial infection and stress [10]. Nevertheless, the exact role of pDC remains unclear. Plasmacytoid dendritic cells constitute a minor population of DC in the blood and can be found both in primary and secondary lymphoid organs. In normal conditions pDC can recognize pathogenic nucleic acids, but they are tolerant to self DNA/RNA released from the cells during apoptosis or necrosis. Breaching tolerance to self nucleic acids could lead to autoimmunity [22]. It includes forming self DNA complexes with anti-DNA antibodies like in systemic lupus erythematosus or aggregation of self DNA with the antimicrobial polypeptide LL37 described in psoriasis [23, 24].

In our study, we used immunohistochemical staining to determine inflammatory infiltrate compo- sition in CHS. Similar studies on $\mathrm{mDC}$ and $\mathrm{pDC}$ balance have been conducted in atopic dermatitis (AD), lupus erythematosus and psoriasis. In AD there is an increase of $\mathrm{pDC}$ in peripheral blood, when in fact their amount in the epidermis is barely detectable. Furthermore, it could result in eczema herpeticum [25]. By contrast, in other chronic inflammatory skin disorders (psoriasis and lupus erythematosus) migration of pDC into damaged skin is significantly higher [26]. Moreover, abundant presence of pDC has been described in certain skin tumors such as basal cell carcinoma, melanoma and squamous cell carcinoma in situ [25]. In our previous study we found that BDC are present in normal skin (mDC in epidermis, pDC in dermis) [8]. In this study we observed that a positive CHS response is linked with a decrease of $\mathrm{pDC}$ and increasing number of $\mathrm{mDC}$. It has been suggested that migration of $\mathrm{pDC}$ is mediated by a recently discovered adipokine - chemerin. Chemerin, first described in psoriatic skin lesions, seems to be an important chemoattractant which triggers an inflammatory response in damaged skin [27]. The lower migration rate of pDC in contact hypersensitivity is probably caused by insignificant or suppressed chemerin expression in the epidermis. Apart from chemerin, there are also other attractants, which could be responsible for engaging $\mathrm{pDC}$, such as adenosine and anaphylatoxins C3a and C5a. However, their hypothetical role in the elicitation phase of CHS needs to be fully investigated [28, 29]. Based on our results, one may assume that the imbalance between $\mathrm{pDC}$ and $\mathrm{mDC}$ may be the key to under- 
standing the effector phase of CHS and may clarify its accurate etiology.

\section{ACKNOWLEDGMENTS}

The study was funded by the National Center of Science grants no. NN401063236 and 2012/05/B/ NZ5/01885 and the Medical University of Lodz, project no. 503/1-152-01/503-01.

\section{CONFLICT OF INTEREST}

The authors declare no conflict of interest.

\section{References}

1. MacDonald K.P., Munster D.J., Clark G.J., Dzionek A., Schmitz J., Hart D.N.: Characterization of human blood dendritic cell subsets. Blood 2002, 13, 4512-4520.

2. Steinman R.M., Cohn Z.: Identification of a novel cell type in peripheral lymphoid organs of mice. II. Functional properties in vitro. J Exp Med 1974, 140, 380-397.

3. Steinman R.M., Cohn Z.: Identification of a novel cell type in peripheral lymphoid organs of mice. I. Morphology, quantitation, tissue distribution. J Exp Med 1973, 138, 1142-1162.

4. Liu K., Nussenzweig M.C.: Origin and development of dendritic cells. Immunol Rev 2010, 1, 45-54.

5. Steinman R.M., Gutchinov B., Witmer M.D., Nussen zweig M.C.: Dendritic cells are the principal stimulators of the primary mixed leukocyte reaction in mice. J Exp Med $1983,2,613-627$.

6. NussenzweigM.C., Steinman R.M., Gutchinov B., Cohn Z.: Dendritic cells are accessory cells for the development of anti-trinitrophenyl cytotoxic T lymphocytes. J Exp Med 1980, 158, 1070-1084.

7. Collin M., McGovern N., Haniffa M.: Human dendritic cell subsets. Immunology 2013, 140, 22-30.

8. Narbutt J., Lesiak A., Zak-Prelich M., Woźniacka A., Sysa-Jedrzejowska A., Tybura M., et al.: The distribution of peripheral blood dendritic cells assayed by a new panel of anti-BDCA monoclonal antibodies in healthy representatives of the Polish population. Cell Mol Biol Lett 2004, 3, 497-509.

9. Hsieh C.S., Macatonia S.E., Tripp C.S., Wolf S.F., O'Garra A., Murphy K.M.: Development of Th1 CD4+ T cells through IL-12 produced by Listeria-induced macrophages. Science 1993, 260, 547-549.

10. Kushwah R., Hu J.: Complexity of dendritic cell subsets and their function in the host immune system. Immunology 2011, 133, 409-419.

11. Jarrossay D., Napolitani G., Colonna M., Sallusto F., Lanzavecchia A.: Specialization and complementarity in microbial molecule recognition by human myeloid and plasmacytoid dendritic cells. Eur J Immunol 2001, 31, 3388-3393.

12. Kadowaki N., Ho S., Antonenko S., Malefyt R.W., Kastelein R.A., Bazan F., et al.: Subsets of human dendritic cell precursors express different Toll-like receptors and respond to different microbial antigens. J Exp Med 2001, 194, 863-869.

13. Gill M., Bajwa G., George T., Dong C.C., Dougherty I.I., Jiang N., et al.: Counterregulation between the FcepsilonRI pathway and antiviral responses in human plasmacytoid dendritic cells. J Immunol 2010, 184, 5999-6006.
14. Bangert C., Friedl J., Stary G., Stingl G., Kopp T.: Immunopathologic features of allergic contact dermatitis in humans: participation of plasmacytoid dendritic cells in the pathogenesis of the disease? J Invest Dermatol 2003, 121, 1409-1418.

15. Girard-Madoux M., Kel J.M., Reizis B., Clausen B.E.: IL-10 controls dendritic cell-induced T-cell reactivation in the skin to limit contact hypersensitivity. J Allergy Clin Immunol 2012, 129, 143-150.

16. Fitzpatrick T.B.: The validity and practicality of sun-reactive skin types I through VI. Arch Dermatol 1988, 124, 869-871.

17. Dzionek A., Fuchs A., Schmidt P., Cremer S., Zysk M., Miltenyi S., et al.: BDCA-2, BDCA-3, and BDCA-4: three markers for distinct subsets of dendritic cells in human peripheral blood. J Immunol 2000, 165, 6037-6046.

18. Cher D.J., Mosmann T.R.: Two types of murine helper T cell clone. II. Delayed-type hypersensitivity is mediated by Th1 clones. J Immunol 1987, 138, 3688-3694.

19. Clausen B.E., Kel J.M.: Langerhans cells: critical regulators of skin immunity? Immunol Cell Biol 2010, 88, 351-360.

20. Chu C.C., Di Meglio P., Nestle F.O.: Harnessing dendritic cells in inflammatory skin diseases. Semin Immunol 2011, 23, 28-41.

21. Lesiak A., Norval M., Sysa-Jedrzejowska A., Wozniacka A., Kobos J., Omulecka A., et al.: Elicitation of contact hypersensitivity after repeated suberythemal exposures of humans to solar simulated radiation: number of epidermal Langerhans cells. Contact Dermatitis 2007, 57, 224-229.

22. Gilliet M., Cao W., Liu Y.J.: Plasmacytoid dendritic cells: sensing nucleic acids in viral infection and autoimmune diseases. Nat Rev Immunol 2008, 8, 594-606.

23. Lövgren T., Eloranta M.L., Båve U., Alm G.V., Rönnblom L.: Induction of interferon-alpha production in plasmacytoid dendritic cells by immune complexes containing nucleic acid released by necrotic or late apoptotic cells and lupus IgG. Arthritis Rheum 2004, 50, 1861-1872.

24. Lande R., Gregorio J., Facchinetti V., Chatterjee B., Wang Y.H., Homey B., et al.: Plasmacytoid dendritic cells sense self-DNA coupled with antimicrobial peptide. Nature 2007, 449, 564-569.

25. Wollenberg A., Wagner M., Gunther S., Towarowski A., Tuma E., Moderer M., et al.: Plasmacytoid dendritic cells: a new cutaneous dendritic cell subset with distinct role in inflammatory skin diseases. J Invest Dermatol 2002, 119, 1096-1102.

26. Farkas L., Beiske K., Lund-Johansen F., Brandtzaeg P., Jahnsen F.L.: Plasmacytoid dendritic cells (natural interferon-alpha/beta-producing cells) accumulate in cutaneous lupus erythematosus lesions. Am J Pathol 2001, 159, 237-243.

27. Nagpal S., Patel S., Jacobe H., DiSepio D., Ghosn C., Malhotra M., et al.: Tazarotene-induced gene 2 (TIG2), a novel retinoid-responsive gene in skin. J Invest Dermatol 1997, 109, 91-95.

28. Gutzmer R., Köther B., Zwirner J., Dijkstra D., Purwar R., Wittmann M., et al.: Human plasmacytoid dendritic cells express receptors for anaphylatoxins $\mathrm{C} 3 \mathrm{a}$ and $\mathrm{C} 5 \mathrm{a}$ and are chemoattracted to C3a and C5a. J Invest Dermatol 2006, $126,2422-2429$

29. Schnurr M., Toy T., Shin A., Hartmann G., Rothenfusser S., Soellner J., et al.: Role of adenosine receptors in regulating chemotaxis and cytokine production of plasmacytoid dendritic cells. Blood 2004, 103, 1391-13977. 